\author{
®Ю. В. Одинець, М. В. Яворович \\ Харківський національний медичний університет

\section{ЕНДОТЕЛІАЛЬНА ДИСФУНКЦІЯ ЯК ДІАГНОСТИЧНО-ПРОГНОСТИЧНИЙ КРИТЕРІЙ ПЕРЕБІГУ ГЕМОРАГІЧНОГО ВАСКУЛІТУ В ДІТЕЙ}

\begin{abstract}
ЕНДОТЕЛІАЛЬНА ДИСФУНКЦІЯ ЯК ДІАГНОСТИЧНО-ПРОГНОСТИЧНИЙ КРИТЕРІЙ ПЕРЕБІГУ ГЕМОРАГІЧНОГО ВАСКУЛІТУ В ДІТЕЙ. Геморагічний васкуліт належить до групи системних васкулітів і розглядається як генералізований мікротромбоваскуліт. Дане захворювання є однією з актуальних проблем сучасної педіатрії, що зумовлена труднощами у діагностиці на ранніх етапах. Метою дослідження було визначення стану функції ендотелію у дітей з геморагічним васкулітом. 3'ясована залежність порушень системи гемостазу у вигляді гіперкоагуляції від фази та активності процесу. Встановлена наявність ендотеліальної дисфункції у всіх дітей, хворих на геморагічний васкуліт. Зафіксоване збільшення рівня циркулюючих імунних комплексів залежно від перебігу хвороби та підвищення показників Т- і В-лімфоцитів при II-ІІІ ступенях активності процесу. Доведена можливість використовування малоінвазивних ультразвукових методів для визначення стану функції ендотелію.

ЭНДОТЕЛИАЛЬНАЯ ДИСФУНКЦИЯ КАК ДИАГНОСТИЧЕСКИ-ПРОГНОСТИЧЕСКИЙ КРИТЕРИЙ ТЕЧЕНИЯ ГЕМОРРАГИЧЕСКОГО ВАСКУЛИТА У ДЕТЕЙ. ГеморрагическИЙ васкулит относится к группе системных васкулитов и рассматривается как генерализованный микротромбоваскулит. Данное заболевание является одной из актуальных проблем современной педиатрии, которая обусловлена сложностями в диагностике на ранних этапах. Целью исследования было определение состояния функции эндотелия у детей с геморрагическим васкулитом. Определена зависимость нарушений системы гемостаза в виде гиперкоагуляции от фазы и активности процесса. Установлено наличие эндотелиальной дисфункции у всех детей с геморрагическим васкулитом. Зафиксировано увеличение уровня циркулирующих иммунных комплексов в зависимости от течения болезни и повышение показателей Т- и В-лимфоцитов при II-III степенях активности процесса. Доказана возможность использования малоинвазивных ультразвуковых методов для определения состояния функции эндотелия.
\end{abstract}

ENDOTHELIAL DYSFUNCTION AS A DIAGNOSTIC AND PROGNOSIS CRITERION OF HEMORRHAGIC VASCULITIS COURSE IN CHILDREN. The hemorrhagic vasculitis is from the group of systemic vasculitis and seen as a generalized microthrombovasculitis. The disease is one of the actual pediatrics problems, which is due to diagnosis difficulties in the early stages. The purpose of the study was to determine the endothelial function status in children with hemorrhagic vasculitis. The relation between of hemostatic disorders and process activity was determined. The endothelial dysfunction is presence in all children with hemorrhagic vasculitis. The correlation between circulating immune complexes levels, indexes of T- and B-lymphocytes and the disease severity was detected. The using possibility of minimally invasive ultrasonic methods for determining the endothelial function state was proved.

Ключові слова: геморагічний васкуліт, дисфункція ендотелію, циркулюючі імунні комплекси, гемостаз, комплекс інтима-медіа, проба реактивної гіперемії.

Ключевые слова: геморрагический васкулит, дисфункция эндотелия, циркулирующие иммунные комплексы, гемостаз, комплекс интима-медиа, проба реактивной гиперемии.

Key words: hemorrhagic vasculitis, endothelial dysfunction, circulating immune complexes, hemostasis, intima-media complex, sample of reactive hyperemia.

ВСТУП. Геморагічний васкуліт (ГВ) належить до групи системних васкулітів і розглядається як генералізований мікротромбоваскуліт, в основі якого лежать асептичне запалення та дезорганізація стінок мікросудин, що уражають судини шкіри і внутрішніх органів у системі мікроциркуляції [1]. Поширеність захворювання складає від 13 до 20 випадків на 100000 дитячого населення, пік захворюваності припадає на вікові групи 4-7 і 12-14 років, хлопчики хворіють у 2 рази частіше. Спроби багатьох авторів пояснити патогенетичну сутність цієї хвороби знайшли відображення у пропонованих різних їі назвах: атромбоцитопенічна пурпура, інфекційно-токсична пурпура, геморагічний васкуліт, капіляротоксикоз, алергічна пурпура [2]. На жаль, діагностика ГВ не завжди буває вчасною. А відстрочка адекватної терапії сприяє виникненню ускладнень, погіршуючи прогноз, що, у свою чергу, пов'язано з поліетіологічністю захворювання і складністю патогенетичних механізмів [3]. ГВ є однією з актуальних проблем сучасної педіатрії, що зумовлена труднощами у діагностиці на ранніх етапах, підвищенням захворюваності у всіх вікових групах, що може бути пов'язано з посиленням алергізуючої дії лікарських препаратів і харчових продуктів, наявністю хронічних інфекцій. За даними ряду авторів, в останньому десятиріччі ГВ проявляється більш тяжким, рецидивним перебігом з переважанням змішаних форм. Часте залучення в патологічний процес нирок визначає тяжкість захворювання та його прогноз [4].

В основі розвитку ГВ лежать утворення імунних комплексів і активація компонентів системи комплементу, які мають шкідливу дію на судинну стінку. Активовані антигенами моноцити і лімфоцити скупчують- 


\section{Педіатрія}

ся в ділянках ураження, утворюючи периваскулярні гранульоми, і звільняють цитокіни, тканинний тромбопластин, лізосомальні ензими, в результаті чого посилюються дезорганізація судинної стінки і локальне тромбоутворення [3]. Патогенез захворювання пов'язаний $3 \mathrm{lgA-імунокомплексним} \mathrm{пошкодженням}$ інтими дрібних судин, що призводить до ендотеліальної дисфункції зі зменшенням синтезу ендотеліальних активаторів фібринолізу [5, 6]. Збільшення комплексу інтима-медіа загальної сонної артерії вважають предиктором розвитку серцево-судинної патології [7]. До неінвазивних методів скринінгового дослідження стану ендотелію належить ультразвукове дуплексне ангіосканування, яке останнім часом в алгоритмі діагностичної програми займає одне з провідних місць внаслідок його неінвазивності, безпеки, а також високої чутливості й специфічності $[8,9]$.

Метою даного дослідження було визначення ступеня дисфункції ендотелію у дітей з геморагічним васкулітом залежно від віку, статі хворих, характеру перебігу, активності захворювання та стану фагоцитарної, клітинноїта гуморальноїланок імунітету.

МАТЕРІАЛИ ТА МЕТОДИ. Обстежено 32 дитини, хворих на геморагічний васкуліт, віком від 4 до 17 років, які перебували на лікуванні в гематологічному відділенні КУОЗ «Харківська міська клінічна дитяча лікарня № 16». Діагноз захворювання верифікували та встановлювали за допомогою загальноприйнятих клініко-лабораторних та інструментальних показників згідно з протоколом МОЗ України № 676 від 12.10.2006 року.

При госпіталізації в лікарню ретельно вивчались скарги хворого, анамнез життя та захворювання, уточнювалися алергологічний анамнез та наявність хронічних вогнищ інфекції. Згідно з класифікацією ГВ, проводився розподіл за формами захворювання (шкірна, шкірно-суглобова, шкірно-суглобова з абдомінальним (змішана) та нирковим синдромами).

Всім дітям з ГВ проведені загальноклінічні дослідження крові та сечі. Біохімічні дослідження крові включали визначення білків гострої фази запалення (серомукоїду, глікопротеїнів) загальноприйнятим методом, аутокоагуляційного тесту (АКТ) (3. С. Баркаган, 1975), протромбінового індексу (ПТІ) за Quick (1943) та фібриногену крові за Rutberg (1959), вмісту загального білка крові - уніфікованим біуретовим методом (В. Г. Колб, В. С. Камишніков, 1972), фракціонування білків - методом горизонтального електрофорезу, визначення рівнів сечовини, креатиніну крові (В. В. Меньшиков, 1987), кліренсів сечовини та ендогенного креатиніну, реабсорбції та швидкості клубочкової фільтрації за кліренсом ендогенного креатиніну, прив'язаного до стандартної площі поверхні тіла (А. Гиттер, Л. Хейльмейер, 1966), а також проводилось дослідження клітинної та гуморальної ланок імунітету (CD3, CD4, CD8, CD16, CD22 в абсолютних та відносних величинах методом визначення субпопуляцій Т- і В-лімфоцитів за допомогою діагностикума «НВЛ Гранум» (Україна), рівнів $\lg \mathrm{A}, \lg \mathrm{M}$, IgG сироватки крові методом G. Mancini (1965) за допомогою реагентів ФГУП «НПО «Микроген» (МЗ РФ Росія), циркулюючих імунних комплексів (ЦІК) за ме- тодом V. Haskova (1978), показників фагоцитозу (нейтрофіли фагоцитуючі, фагоцитарне число та індекс активності нейтрофілів) за принципом здатності поліморфноядерних лейкоцитів та моноцитів периферичної крові пов'язувати на своїй поверхні, поглинати і перетравлювати мікробну тест-культуру, NST-тестуза Стюарт (1975) в модифікації Б. С. Нагоєва (1983)).

Всім дітям проводилися дослідження товщини комплексу інтима-медіа загальної сонної артерії методом ультразвукового дуплексного сканування в дистальній третині загальної сонної артерії за P. Pignolli (1986), проба реактивної гіперемії за методикою, запропонованою D. Celermajer та співавт. (1992), та визначення показників кількісної оцінки параметрів кровотоку на цифровому доплерівському ультразвуковому діагностичному комплексі Ultima PA $з$ використанням лінійного датчика 10-15 МГц.

Групу контролю склали 15 практично здорових дітей аналогічного віку і статі.

Статистична обробка отриманих нами результатів була проведена в пакеті STATISTICA 7.0 FOR WINDOWS із застосуванням параметричних та непараметричних методів оцінки отриманих результатів.

РЕЗУЛЬТАТИ ДОСЛІДЖЕННЯ ТАЇХ ОБГОВОРЕННЯ. Основну групу склали 32 дитини, з них 12 (38\%) дівчаток та 20 (63\%) хлопчиків. Аналіз клінічних особливостей ГВ у дітей свідчить про його «омолодження», зокрема $66 \%$ випадків ГВ припадає на вік від 4 до 7 років. Хворі поділені на групи за характером і тяжкістю перебігу (ступінь активності). У 9 хворих (1 група) встановлено легкий перебіг (І ст. активності), у 14 хворих (2 група) - середню тяжкість (II ст. активності) й у 9 хворих (3 група) - тяжкий перебіг (III ст. активності). У 71,9 \% хворих, за якими ми спостерігали, реєстрували II-ІІІ ступені активності, що підкреслює переважання тяжкого перебігу хвороби.

На оцінку ступеня активності вплинули клінічні прояви захворювання в дебюті, також критеріями ступеня тяжкості процесу стали: рівень лейкоцитів крові, ШОЕ, серомукоїду та гаммаглобулінів, які $\epsilon$ показниками гостроти запального процесу.

Відносно стану системи гемостазу можна відмітити, що в гострий періоду хворих усіх груп, від мінімального до максимального ступеня активності ГВ, реєструється значна гіперкоагуляція. Рівень гіперкоагуляції перебуває в прямій залежності від фази та активності процесу, її вираження є наслідком як активації коагуляційного потенціалу крові, так і зниження функційної активності системи протизгортання крові.

Щодо характеру специфічних та неспецифічних факторів захисту при геморагічному васкуліті у дітей, то вони зазнають суттєвих змін. Так, підвищуються рівні ЦІК залежно від тяжкості процесу. У хворих 1 групи середні значення ЦІК склали $68,7 \pm 9,09$ ум. од.,

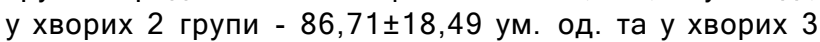

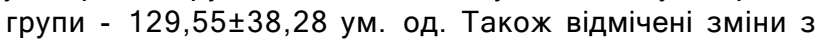
боку клітинноїта гуморальноїланок імунітету. В дітей 3 легким перебігом захворювання середнє значення CD3 дорівнювало $1,54 \pm 0,14-10^{9} / л$, перебуваючи в межах нормальних величин. Проте у хворих 2 групи цей рівень складав $2,61 \pm 0,86-10^{9}$ /л та у дітей 3 гру- 


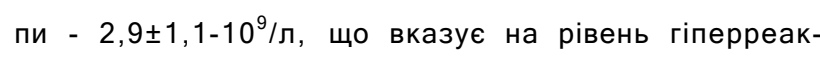
тивності імунної системи. Аналогічні зміни спостерігали і відносно показників CD22.

Щодо інструментальних методів дослідження, то у дітей з легким перебігом хвороби товщина комплексу інтима-медіа склала 0,66 0,2 мм та середньотяжким перебігом - 0,62 $\pm 0,2$ мм, що є варіантом норми. Тоді як у дітей з тяжким перебігом ГВ середня товщина комплексу інтима-медіа дорівнювала $1,04 \pm 0,2$ мм. Тому даний показник може виступати маркером тяжкості процесу. При проведенні проби реактивної гіперемії у всіх хворих, незалежно від тяжкості перебігу та форми захворювання, ступінь максимального розширення плечової артерії після оклюзії склала мінус $11,92 \pm 0,04 \%$, тоді як нормальною прийнято вважати дилатацію більш ніж на 10,0\% від вихідного діаметра. Наведені дані свідчать про безперечну наявність ендотеліальної дисфункції у всіх дітей, хворих на ГВ.

У хворих 1 групи виявлені кореляційні зв'язки між рівнями ШОЕта ЦІК $(r=+0,72, p<0,05)$, між рівнями гаммаглобулінів і ЦІК $(r=+0,64, p<0,05)$. У хворих 2 групи кореляційні зв'язки визначені між рівнями CD3 та ЦІК $(r=+0,34, p<0,05)$, а також між показниками CD22 і ЦІК $(\ulcorner=+0,38, p<0,05)$. У хворих 3 групи реєструється кореляційний зв'язок між значенням комплексу інтимамедіа та ЦІК $(r=+0,31, p<0,05)$, між показниками комплексу інтима-медіа та рівнем CD3 $(r=+0,51, p<0,05)$, між значеннями CD3 та ЦІК $(r=+0,41, p<0,05)$. Показово, що у хворих всіх груп існує зворотний кореляційний зв'язок між показниками ЦІК та діаметра плечової артерії на 30 с після оклюзії $(r=-0,54, p<0,05)$.

ВИСНОВКИ. Таким чином, виявлено, що серед обстежених хворих на ГВ на вік від 4 до 7 років припадає 66 \% дітей, у 71,9 \% реєструються II-III ступені активності процесу, що підкреслює переважання тяжкого перебігу хвороби. У всіх хворих реєструються зміни в системі гемостазу у вигляді гіперкоагуляції. Рівень гіперкоагуляційного зсуву перебуває в прямій залежності від фази та активності процесу. Зафіксовано зростання рівня ЦІК залежно відтяжкості перебігу ГВ, що може використовуватись як маркер ступеня активності процесу. Підвищення Т- та В-лімфоцитів спостерігалось лише при II-III ступенях активності ГВ. Товщина комплексу інтима-медіа збільшувалась тільки при тяжкому перебігу хвороби. Тому даний показних може виступати маркером тяжкості процесу. Підтверджена наявність ендотеліальної дисфункції у всіх хворих на ГВ дітей.

ПЕРСПЕКТИВИ ПОДАЛЬШИХ ДОСЛІДЖЕНЬ ПОлягають у дослідженні молекулярних маркерів пошкодження ендотелію судинного русла та визначенні метаболітів оксиду азоту в сироватці крові, що дозволить отримати більш детальні дані про роль ендотеліальних порушень у механізмах розвитку та перебігу геморагічного васкуліту в дітей.

\section{СПИСОК ЛІТЕРАТУРИ}

1. Третьякова О. С. Пурпура Шенлейна - Геноха у детей: клинико-диагностические подходы / О. С. Третьякова // Дитячій лікар. - 2011. - № 5. C. 8-16.

2. Лыскина Г. А. Некоторые аспекты развития, течения и лечения болезни Шенлейна-Геноха у детей / Г. А. Лыскина, Г. А. Зиновьева // Педиатрия. 2010. - Т. 89, № 6. - С. 131-136.

3. Геморрагический васкулит у детей : учебнометодическое пособие / Т. И. Козарезова, Н. Н. Климкович, В. А. Кувшинников, С. Н. Козарезов. - Мн. : БелМАПО, 2007. - С. 39.

4. Король Т. Г. Клінічні особливості перебігу пурпури Шенлейн-Геноха у дітей / Т. Г. Король // Вісник Вінницького національного медичного університету. - 2014. - T. 18, № 2. - С. 554-557.

5. Endothelial dysfunction: a comprehensive appraisal / R. J. Esper, R. A. Nordaby, J. O. Vilarino, A. Paragano //
Cardiovasc. Diabetol. - 2006. - Vol. 54. - P. 14752840.

6. Davin J. C. Diagnosis of Henoch-Schonlein purpura: renal or skin biopsy? / J. C. Davin, J. J. Weening // Pediatr. Nephrol. - 2007. - Vol. 18. - P. 1201-1203.

7. Петрищев Н. Н. Типовые формы дисфункции эндотелия / Н. Н. Петрищев // Дисфункция эндотелия. Патогенетическое значение и методы коррекции / под ред. Н. Н. Петрищева, Т. Д. Власова. - СПб. : ИИЦВМА, 2007. - 296 с.

8. Строгий В. В. Состояние артериального кровотока у подростков из групп сердечно-сосудистого риска / В. В. Строгий // Медицинская панорама. 2008. - № 6. - С. 33-36.

9. Терегулов Ю. Э. К методологии проведения пробы и оценки эндотелий-зависимой дилатации плечевой артерии / Ю. Э. Терегулов, Д. К. Хусаинова, И. Г. Салихов // Эхография. - 2004. - № 3. - С. 217-221. 